\title{
Crimes of the Powerful: The Canadian Context
}

\author{
Steven Bittle ${ }^{1} \cdot$ Dean Curran ${ }^{2} \cdot$ Laureen Snider $^{3}$
}

Published online: 8 October 2018

(c) Springer Nature B.V. 2018

\section{Introduction}

Crimes of the powerful scholarship has grown in recent decades, particularly following the 2007/08 global financial crisis and the discovery of numerous environmental and political crimes by powerful actors, institutions and organizations. Much of this literature has focused on crimes of the powerful in the US, UK and international fora (for example, Barak 2015, 2017; Bittle et al. 2018; Tombs and Whyte 2015; Rothe and Kauzralich 2016; Will et al. 2013). Relatively few published studies have examined the Canadian context (for exceptions see Bittle 2012; Glasbeek 2017; Snider 2015), despite the fact that many/ most crimes of the powerful transcend national boundaries. This special issue of Critical Criminology, by critically exploring theoretical and empirical issues relating to crimes of the powerful within the Canadian context and/or from a Canadian perspective, will remedy this omission.

Canada provides a particularly interesting case study, with its geographic, economic and cultural ties to the US and its historic ties to the UK and France. When compared to the US, especially after the election of Donald Trump, Canada is often portrayed as a model liberal democracy, one of the few that has maintained its social democratic roots. The rock star status of the current Prime Minister, Justin Trudeau (with his appearance on the cover of Rolling Stone magazine to boot!), has become a signifier and a symbol of possibilities for other nations. However, beneath this shiny veneer is a nation that is much more similar to its neighbour to the south, and to all nations swept-up by the dogmas of neoliberalism, globalism and corporate capitalism, than is commonly believed. Trudeau's Liberal government, for instance, while less socially conservative than its predecessor, has supported the controversial Kinder Morgan pipeline (despite campaigning on a green economy platform) (McKibben 2018) and quietly introduced US-style deferred prosecution agreements for corporate offenders (van Praet 2018). In addition, the recent election of a populist conservative premier in the province of Ontario (Canada's most populated province) demonstrates how Canada is not isolated from the divisive politics of the $1 \%$ found in the US and beyond.

Steven Bittle

sbittle@uottawa.ca

1 University of Ottawa, Ottawa, Canada

2 University of Calgary, Calgrary, Canada

3 Queen's University, Kingston, Canada 
As these articles demonstrate, Canada fully embraces its own brand of neoliberalism where crimes of power abound and the state is either powerless to act, or complicit. While neoliberalism is not "one thing", as Hall (2015: 16) has noted, it is now abundantly clear that, “...geopolitically, neoliberal ideas, policies and strategies are incrementally gaining ground, re-defining the political, social and economic model, governing the strategies and setting the pace" (Hall 2015, 16). Canada is thus not immune to the illusions of modern liberal democracies that perpetuate the myth of the rule of law, where states and corporations exist in increasingly "symbiotic" relationships (Tombs and Whyte 2015)—one which makes it difficult (albeit not impossible) and contradictory for states to discipline powerful actors and institutions - and where hegemonic beliefs prevail about the inherent benefits of private enterprise, minimal state regulation of business (unless the state's intervention facilitates the private accumulation of wealth), and hyper-individualism prioritizing personal wealth and accomplishment over collective solidarity. It is our hope, therefore, that this special issue helps put a dent Canada's shiny image, therein reminding us about the importance of scrutinizing the crimes of the powerful in all of its locales and (dis)guises and unearthing the vulnerabilities and contradictions of capitalism's imaginary social order (Pearce 1976).

\section{Articles}

The issue begins, appropriately enough, with an analysis by Elizabeth Comack (University of Manitoba) of the crimes of power that founded Canada: the theft of the lives, cultures and resources of the aboriginal peoples who occupied the territory that is now Canada before European settlers arrived. Comack traces the continuation of these crimes, from the residential schools that forcibly removed indigenous children from their parents and communities to "civilize" them to the theft of resources by extractive industries allied with the Canadian state that continues to this day.

Canada's extractive industries have been mainstays of the Canadian economy from the arrival of the first Europeans on, many of Canada's economic elites trace their fortunes back to furs and timber, gold and silver, coal, uranium, oil and gas. The next three articles examine the influence of such industries today. Caron Weisbart (York University) analyzes the complicity of the Canadian government in enabling the crimes of a Canadian-US owned silver mine in Guatemala, Tahoe Resources and its subsidiary, Minera San Rafael (MSF). She does this through a critical reading of Access to Information (ATI) requests and email correspondence from Global Affairs Canada (GAC) before, during and after a violent shooting at MSF's Guatemalan project site, and argues that the Canadian embassy and GAC, under the guise of 'diplomatic relations' and charity events, engages in "a particular form of state-corporate symbiosis". Garry Gray and William Carroll (University of Victoria) examine institutional corruption in their study mapping the interlocking elite networks between fossil fuel industries and key Canadian universities. Their research shows how university administrators in today's neoliberal environment have tacitly accepted improper corporate influence as "the new reality of funding environments" and in the process have decreased the independence of science as well as jeopardizing public trust in university-based scientific research. The theme of institutional corruption continues in Margaret Beare's (York University) case studies of financial corruption in the construction industry. Her research focuses on the cultures of entitlement that develop within political and financial elites and the mechanisms by which they isolate themselves from 
responsibility despite their acceptance of payoffs (bribes) from organized criminals, the classic scapegoats for such acts of corruption.

Professional corruption is the theme of Joan Brockman's (Simon Fraser University) analysis of doctors reported for sexual misconduct. Like Weisbart, she uses ATI requests to get access to documents that allow her to compare disciplinary decisions taken by the College of Physicians and Surgeons of British Columbia compared to Ontario's College of Physicians and Surgeons. She then analyzes the relative transparency of Ontario's medical regulators compared to their western counterpart and relates it to feminist activism and their influence on networks of power. In so doing, she demonstrates how ATI legislation can paradoxically help to expose physicians' misconduct while at the same time reinforcing the lack of transparency around professional self-regulating organizations.

The next two articles examine the latest developments, specifically the impact of new technologies in Canada today. Stephane Leman-Langlois (Université de Laval) traces the damage control responses of the federal government to the release of documents by Edward Snowden, documents that revealed the extent of data interception, analysis and collection of information on Canadian citizens by the Security Establishment. He argues that the practices and the ethos of Canada's security institutions have remained essentially the same despite state attempts to placate public opinion with a series of "reforms" and concludes, using Foucault, that the state treats rule-breaking at the higher echelons of state power very differently from other crimes, applying a very particular form of "management of illegalisms" here. Laureen Snider (Queen's University) describes the almost total failure of legal systems to criminalize, regulate or restrict the crimes of capitalism and its institutions in the "uber/gig" economy. She argues that powerful elites have succeeded in "normalizing" the technologically-enabled theft of time, space and wages by employers from employees and shows how neoliberal capitalism, in its constant search for new ways to outsource costs and maximize profits, intersects with the democratic state and its professed obligation to prevent capital from "going too far" at the expense of citizens of that state.

The final three articles delve into theories explaining the realities of neoliberal capitalism in Canada that the previous articles have, in varying contexts, developed. Of particular interest for these authors is the way that law functions as a "point of articulation" (Hall 1988: 61) for powerful interests to inform law's constitution and to help reproduce the capitalist status quo. Harry Glasbeek (Osgoode Hall Law School, York University) argues that despite law's claims to uphold liberal values, its adherence to the sacrosanct nature of private property, individualism and freedom to contract maintains and perpetuates capitalist goals. He shows how the owners of the means of production are given political and economic privileges that allow them to use law to ignore workers' rights and prevent the working class from achieving the economic and political autonomy that liberal law supposedly promises to all. Dean Curran (University of Calgary) analyzes "organized irresponsibility", showing how certain sets of individuals cumulatively and systematically create and benefit from creating risks for others yet avoid culpability for addressing or ameliorating such risks. Marrying risk literatures (Beck and Giddens) with those documenting increased inequality (Piketty and Savage), he argues that the opportunities for "risk arbitrage" thus created both risk and inequality today. Finally, Steven Bittle and Jon Frauley (University of Ottawa) use Bourdieu's notion of "praxeological" sociology and Althusser's concept of "mis/recognition" as the theoretical bases of what they argue is a more robust theory of regulation and compliance than commonly employed in corporate crime literatures. They empirically demonstrate the benefits of this approach by examining state efforts to discipline corporations through criminal law in Canada and the United Kingdom, arguing that law's rational actor model serves to have us "misrecognize" the genesis of corporate 
offending and, in the process, "reproduces the myth that compliance is a distinctly legal phenomenon."

\section{References}

Barak, G. (Ed.). (2015). The Routledge international handbook of the crimes of the powerful. London: Routledge.

Barak, G. (2017). Unchecked corporate power: Why the crimes of multinational corporations are routinized away and what we can do about it. London: Routledge.

Bittle, S. (2012). Still dying for a living: Corporate criminal liability after the Westray Mine Disaster. Vancouver: UBC Press.

Bittle, S., Snider, L., Tombs, S., \& Whyte, D. (Eds.). (2018). Revisiting crimes of the powerful: Marxism, crime and deviance. London: Routledge.

Glasbeek, H. (2017). Class privilege: How law shelters shareholders and coddles capitalism. Toronto: Between the Lines.

Hall, S. (1988). The toad in the garden: Thatcherism among the theorists. In C. Nelson \& L. Grossberg (Eds.), Marxism and the interpretation of culture. Urbana and Chicago: University of Illinois Press.

Hall, S. (2015). The neoliberal revolution. In S. Davison \& K. Harris (Eds.), The neoliberal crisis: A soundings collection. London: Lawrence \& Wishart.

McKibben, B. (2018). Say hello to Justin Trudeau, the world's newest oil executive. The Guardian. Accessed September 21, 2018, from https://www.theguardian.com/commentisfree/2018/may/29/justin-trudeauworld-newest-oil-executive-kinder-morgan.

Pearce, F. (1976). The crimes of the powerful: Marxism, crime and deviance. London: Pluto Press.

Rothe, D., \& Kauzralich, D. (2016). Crimes of the powerful: An introduction. London: Routledge.

Snider, L. (2015). About Canada: Corporate crime. Winnipeg, MB: Fernwood.

Tombs, Steve, \& Whyte, David. (2015). The corporate criminal: Why corporations must be abolished. London: Routledge.

van Praet, N. (2018). Corporate-misconduct laws could aid SNC-Lavalin. Globe and Mail. Accessed September 21, 2018, from https://www.theglobeandmail.com/report-on-business/snc-lavalin-shares-riseas-ottawa-moves-ahead-on-deferred-prosecutions/article38085435/.

Will, S., Handelman, S., \& Botherton, D. (Eds.). (2013). How they got away with it: White collar criminals and the financial meltdown. New York: Columbia University Press. 